AperTO - Archivio Istituzionale Open Access dell'Università di Torino

Ground Zoning Map of the Piedmont Region (NW Italy): methodology and preliminary results

This is a pre print version of the following article:

Original Citation:

Availability:

This version is available http://hdl.handle.net/2318/151954

since 2017-05-25T08:45:52Z

Publisher:

Springer

Published version:

DOI:10.1007/978-3-319-09048-1_202

Terms of use:

Open Access

Anyone can freely access the full text of works made available as "Open Access". Works made available under a Creative Commons license can be used according to the terms and conditions of said license. Use of all other works requires consent of the right holder (author or publisher) if not exempted from copyright protection by the applicable law. 


\section{(3) \\ UNIVERSITÀ DEGLI STUDI DI TORINO}

This is an author version of the contribution published on:

Questa è la versione dell'autore dell'opera:

G. Lollino et al. (eds.). Engineering Geology for Society and Territory - Volume 5 DOI : 10.1007/978-3-319-09048-1_202

Springer International Publishing Switzerland 2015

$$
\text { p. 1065-1069 }
$$

The definitive version is available at:

La versione definitiva è disponibile alla URL:

http://www.springer.com/us/book/9783319090474 


\title{
Ground Zoning Map of the Piedmont Region (NW Italy): Methodology and Preliminary Results
}

Perrone Gianluigi, Gaeta Armando Riccardo, Tiranti Davide, Cadoppi Paola, Fioraso Gianfranco

G. Perrone, P. Cadoppi

Department of Earth Sciences, University of Torino, Turin, Italy

e-mail: gianluigi.perrone@unito.it

A.R. Gaeta D. Tiranti

Department of Forecasting Systems, Regional Agency for

Environmental Protection of Piemonte, Turin, Italy

G. Fioraso

Institute of Geosciences and Georesources, National Research

Council, Turin, Italy

P. Cadoppi

NatRisk, University of Torino, Turin, Italy

\begin{abstract}
This paper briefly describes the methodology and preliminary results of a study aimed at the realization of a Ground Zoning Map of the Piedmont region, characterized by low-to-moderate seismic hazard. In this study, two thematic maps were produced, namely a Lithotechnical map and a Ground Zoning Map of the Piedmont region at 1:250,000 scale. In the Lithotechnical map, the geological units were grouped, on the basis of their strength properties, grain-size, density and weathering of rocks, into 24 categories qualitatively characterized by a homogeneous seismic response. In the Ground Zoning Map, the regional territory was subdivided into three main sectors characterized by homogeneous mechanical behaviour during seismic shaking. These areas were further subdivided into several zones characterized by homogenous lithostratigraphy and/or geo-structural conditions. These maps should constitute the basis for the realization of an updated $\mathrm{VS}_{30}$ map of the Piedmont region, which is currently lacking.
\end{abstract}

\section{Introduction}

The Piedmont region is characterized by a low magnitude seismicity (less than 5 on the Richter scale), mainly clustered in its western sector, alongside the western Alps and in its south-eastern sector alongside the Langhe sector (Perrone et al. 2013 and references therein). In the new seismic classification of Italy (President of the Council of Ministers' Ordinance n. 3274, 20th March 2003) a large part of Piedmont falls into Zones characterized by low and very low seismic hazard. The application of the "New Technical Standards for Constructions, 14th January 2008 Ministerial Decree" imposes the earthquake-resistant designs for structures, and the characterization of ground motions for the entire regional territory. These recommendations are based, following the Eurocode 8 directives (BS EN 1998-1:2004, 2004), on the definition of the Vs 30 parameter. In this paper, the methodological approach and preliminary results of a study aimed at the realization of thematic maps for the seismic site characterization of the Piedmont region are described. These maps should constitute the basis for the realization of an updated $\mathrm{Vs}_{30}$ map of the Piedmont region, which is currently lacking.

\section{Methodology}

The paucity of $\mathrm{V}_{\mathbf{3} 3}$ measurements does not allow direct characterization of the site amplification for the entire study area. Nevertheless, the wide availability of geological maps for the whole study area (Geological Map of Italy on a scale of 1:100,000), even if outdated (most of these maps date back to the first half of the last century), induced us to adopt 
a geologically-based strategy for the realization of the thematic maps described in the following. In this strategy, when Vs30 measurements are not sufficiently abundant or unavailable, surficial geological units are assigned a constant Vs30 value on the basis of representative values for a specific geological unit.

In order to update the information regarding this area, geological maps were integrated using GIS software, with the Italian Landslides Inventory (IFFI Project; only landslides wider than $500 \mathrm{~m}$ were considered) and with the Quaternary deposits mapped in the Geological Map of the Piedmont region on a scale of 1:250,000 (Piana et al. in press). A preliminary geological map on a scale of 1 : 250,000 in shapefile format is required as a starting material for the realization of $V_{s} 3$ maps (Wald et al. 2006), resulting from the integration of these different data. Proceeding from this map, two thematic maps, namely the "Lithotechnical Map" and the "Ground Zoning Map" were created. In the Lithotechnical Map the geological units were grouped into different categories on the basis of their strength properties, grain-size, density and weathering of rocks. Each category is considered to be qualitatively characterized by a homogeneous mechanical response to seismic shaking.

The Ground Zoning Map (1:250,000 scale) was created (Figs. 1 and 2) starting from the previous one, in which the regional territory was subdivided into different sectors characterized by homogeneous mechanical behaviour during seismic shaking. These sectors were further subdivided into several zones characterized by a homogenous lithostratigraphy. A preliminary $\mathrm{V}_{30}$ value was assigned to each zone based on the Eurocode 8. Jv and GSI parameters were also assigned, on the basis of the literature, to characterize the fractured bedrock.

This map, despite having a completely different scale, was created using a procedure similar to that proposed for the first level of microzonation studies in Italy (Gruppo di lavoro MS 2008). This methodology has been chosen because, compared to the classical ones (Wills et al. 2000), allows to take into account a greater number of parameters for the characterization of seismic site response, such as: (i) the rock strength of the bedrock, (ii) the thickness of surficial deposits and (iii) the deep-seated gravitational slope deformations (DGSDs) and the fault zones, which cause a strong decrease of the rock mass quality. This allows a more accurate evaluation of the seismic site conditions. In addition, this methodology allows to immediately view, on a regional scale, the different areas qualitatively characterized by different seismic response. This second aspect can be useful both in the land use planning and in the civil protection perspective.

\section{Lithotechnical and Ground Zoning Map}

In the Lithotechnical Map the geological units were grouped into 24 different categories. Two main categories were identified, namely the Quaternary surficial deposits and the pre-Quaternary bedrock. The pre-Quaternary bedrock was further subdivided into (i) metamorphic and (ii) sedimentary consolidated bedrock. The DGSDs and the regional fault zones, responsible for the decrease of the rock mass quality were also considered. 
In the Ground Zoning Map (Figs. 1 and 2), the

regional territory was subdivided into Stable Areas, Stable

Areas possibly affected by seismic amplification and Areas

susceptible to instabilities, represented in blue, green and red

tonalities respectively, on the basis of the lithological characteristics,

rock fracturing and thickness of the surficial

deposits (Gruppo di Lavoro 2008).

In the stable areas, corresponding to areas where poorly

fractured bedrock crops out or is covered by a thin blanket of

Quaternary deposits (less than $5 \mathrm{~m}$ ), no seismic amplification phenomena are likely.

The stable areas possibly affected by seismic amplification

phenomena correspond to areas where strongly fractured

bedrock crops out, or is overlain by surficial deposits

more than $5 \mathrm{~m}$ thick. In these areas, amplification phenomena

during earthquake shaking could occur.

The areas susceptible to instabilities correspond to areas

where permanent deformations, like landslides, could occur.

These three categories were further subdivided into 36

different Zones, characterized by a roughly homogeneous

stratigraphy for the first $30 \mathrm{~m}$ of depth, in which a homogeneous

seismic response was expected. A stratigraphic

column indicating the range of thickness of each lithotype

and a qualitative estimation of its Vs value was also provided

for each Zone. Moreover, Jv and GSI parameters were

also qualitatively provided for the areas affected by DGSDs

and/or fault zones.

In the stable areas, eight Zones were identified (Zones

1-8), where $V_{s_{30}}$ values greater than $800 \mathrm{~m} / \mathrm{s}$ were expected.

These Zones were mostly widespread in the Western Alps,

where poorly fractured metamorphic bedrock crops out and subordinately in the Langhe, Monferrato and Turin Hill,

where coarse-grained sedimentary bedrock (conglomerates,

breccias, sandstones) crops out.

In the stable areas that were likely to be affected by

amplification phenomena, 25 Zones were classified (Zone

9-33), where Vs30 of 360-800 m/s were generally expected.

These Zones, which were mostly widespread in the Po Plain,

Langhe, Monferrato and Turin Hill, and subordinately in the

Western Alps, include:

- areas where metamorphic bedrock, affected by DGSDs, crops out, or is overlapped by Quaternary deposits up to

$30 \mathrm{~m}$ thick; widespread only in the Western Alps;

- fault zones;

- areas where fine-grained sedimentary bedrock (marls, clays, sands, chaotic complexes) crops out, widespread in the Langhe, Monferrato and Turin Hill;

- areas where sedimentary or metamorphic bedrock is overlapped by Quaternary deposits (loess deposits, block streams, glacial till, fluvial deposits, talus deposits) up to $30 \mathrm{~m}$ thick;

- areas where Quaternary deposits (fluvial and subordinately glacial and lacustrine deposits) are more than $30 \mathrm{~m}$ thick, mostly widespread in the Po Plain and in the main bottom valleys;

- areas where anthropic deposits, more than $30 \mathrm{~m}$ thick, are present.

In the stable areas susceptible to instabilities, three Zones were identified (Zones 34-36):

- landslide deposits, up to $30 \mathrm{~m}$ thick, that overlie metamorphic or sedimentary bedrock, possibly characterized

by Vs values greater than $800 \mathrm{~m} / \mathrm{s}$; 
- landslide deposits, up to $30 \mathrm{~m}$ thick, that overlap a bedrock affected by DGSDs, possibly characterized by Vs values of $360-800 \mathrm{~m} / \mathrm{s}$;

- a zone characterised by sinkholes.

\section{References}

BS EN 1998-1:2004 (2004) Eurocode 8, Design of structures for earthquake resistance-Part 1: General rules, seismic actions and rules for buildings. CEN European committee for standardization, Bruxelles, Belgium. ftp://law.resource.org/eur/ibr/en.1998.1.2004. pdf

Gruppo di lavoro MS (2008) Indirizzi e criteri per la microzonazione sismica. Conferenza delle Regioni e delle Province autonomeDipartimento della protezione civile, Roma, 3 vol and Dvd

Perrone G, Morelli M, Piana F, Fioraso G, Nicolò G, Mallen L, Cadoppi P, Balestro G, Tallone S (2013) Current tectonic activity and differential uplift along the Cottian Alps/Po Plain boundary (NW Italy) as derived by PS-InSAR data. J Geodyn 66:65-78

Piana F, Falletti P, Fioraso G, Irace A, Mosca P, D'Atri A (in press) Geological map of the Regione Piemonte, 1: 250,000 scale. CNRIGG, ARPA Piemonte

Wald DJ, Worden BC, Quitoriano V, Pankow KL (2006) ShakeMap® manual, users guide, and software guide, U.S. Geological survey, techniques and methods 12-A1. http://pubs.usgs.gov/tm/2005/

12A01/. Accessed May 2005

Wills CJ, Petersen M, Bryant WA, Reichle M, Saucedo GJ, Tan S, Taylor G, Treiman J (2000) A site-conditions map for California based on geology and shear-wave velocity. Bull Seismol Soc Am 90:S187-S208 


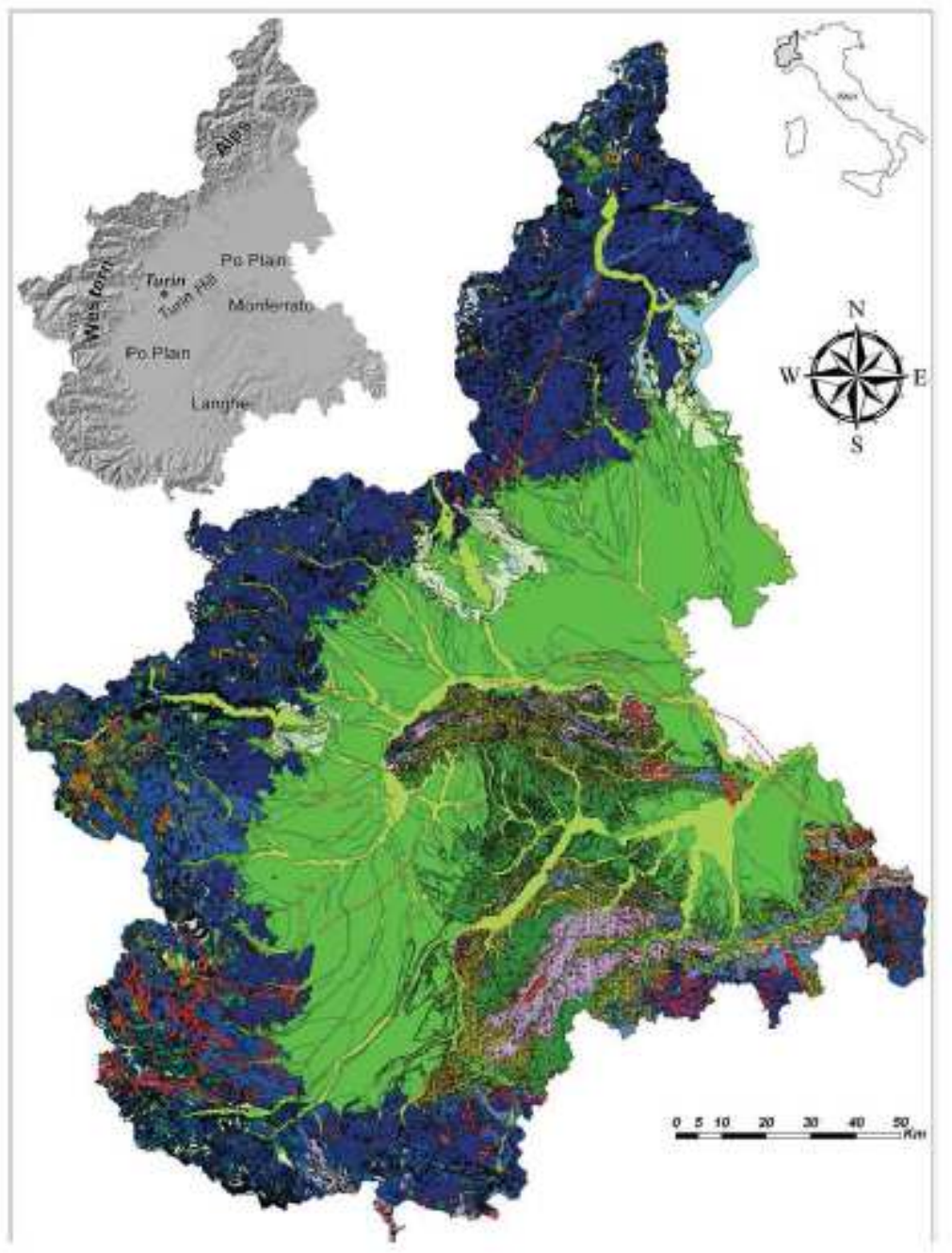

Fig. 1 Preliminury Croumd Zoning Mpap af the Predmant region. The legend of this mapp is illusirned in the Fie. 2 

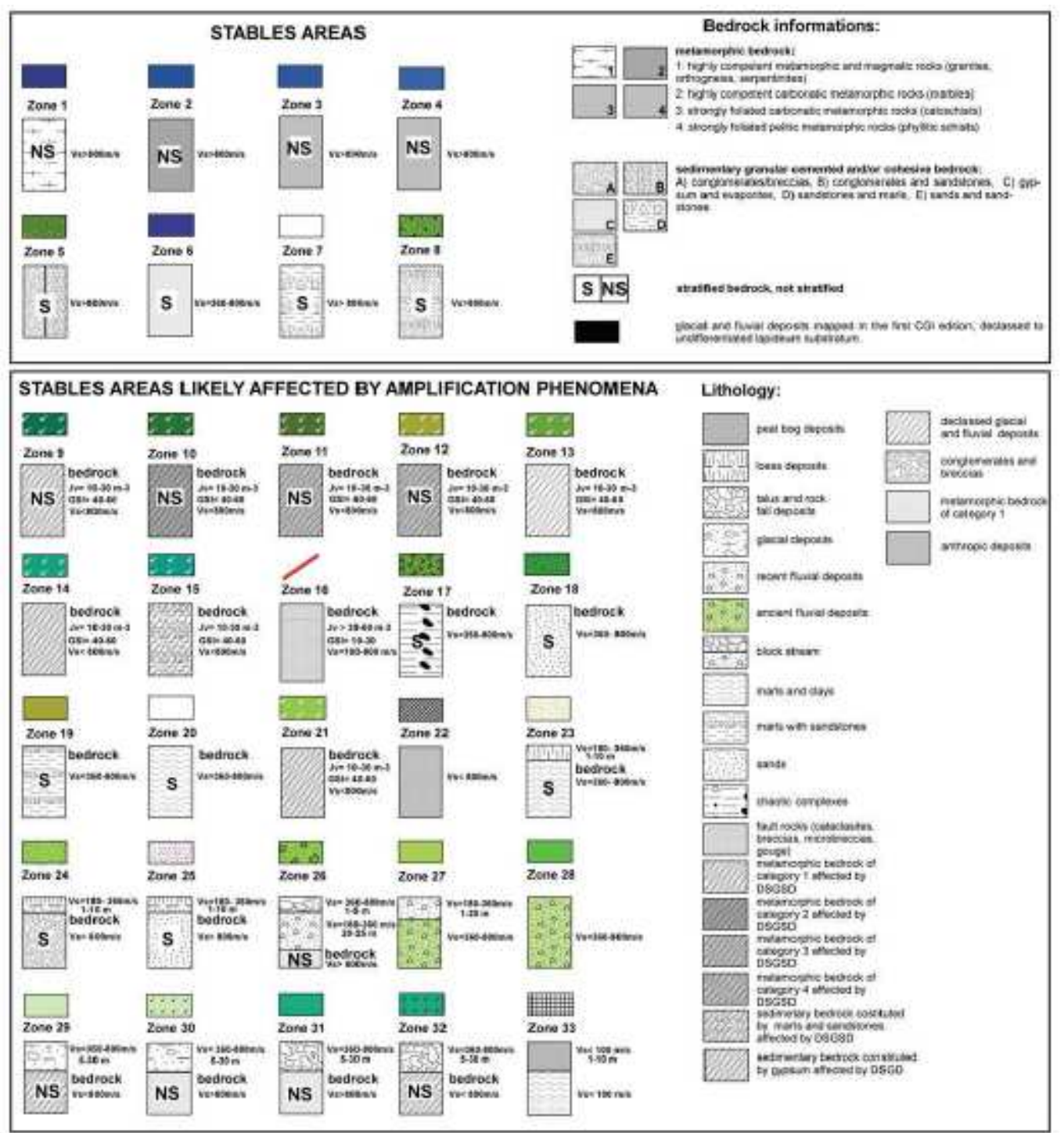

\begin{tabular}{|c|c|c|c|c|c|c|}
\hline \multicolumn{4}{|c|}{ AREAS SUSCEPTIBLE TO INSTABILITIES } & \multicolumn{3}{|c|}{ OTHER SYMBOLS } \\
\hline & & 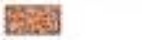 & Lithology: & & & \\
\hline zone 34 & $20=18$ & 20 ane 36 & 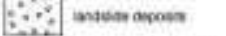 & 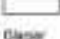 & $m$ & nat \\
\hline $6 y^{200}$ & $\because 3)^{3}$ & $\because 2=\operatorname{sentan}$ & 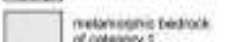 & & 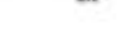 & . \\
\hline $\begin{array}{l}\text { bedroce } \\
\text { wothow }\end{array}$ & 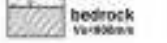 & $\begin{array}{l}\text { bedrock } \\
\text { whomit }\end{array}$ & 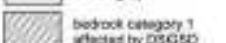 & & & \\
\hline
\end{tabular}

Fig. 2

Fig. 202,2 Legend of Fig. 202,1. In the legend a stntigrahic column hes ben assignal to each Zone, In the columns the thiciness and the Vs values are shown fir the different lithologies. The Iv and GS. I purameters were alwo indiated to churacterine fractured bectrods (faults, DSCSDs) 